\title{
ERRATUM
}

Benjamin H. Taragin - Walter E. Berdon - Beth Printz

\section{MRI assessment of bronchial compression in absent pulmonary valve syndrome and review of the syndrome}

The online version of the original article can be found at: http://dx. doi.org/10.1007/s00247-005-0018-9

\section{B. H. Taragin $(\bowtie) \cdot$ W. E. Berdon}

Department of Radiology, Children's Hospital of New York, 3959 Broadway CHN-3,

New York, NY 10032, USA

e-mail: bentaragin@hotmail.com

Tel.: +1-212-3421654

Fax: +1-212-3057233

B. Printz

Department of Cardiology, Children's Hospital of New York, New York, NY, USA

\section{Pediatr Radiol (2006) 36:71-75}

The name of the third author is Beth Printz. Owing to an unfortunate technical error, her surname was misspelled in the HTML version of the article that appeared online. 